\title{
The Determinants of Intra-Africa Export Performance in Selected African Countries
}

\author{
Abiodun Samuel Isayomi ${ }^{1}$, Temitope Sade Akintunde ${ }^{2^{*}}$ \\ ${ }^{1}$ Department of Economics, Osun State University, Area 210001, Oke Baale street Osogbo, Nigeria \\ e-mail: abiodun.isayomi@uniosun.edu.ng \\ ${ }^{2}$ Department of Economics, Osun State University, Area 210001, Oke Baale street Osogbo, Nigeria \\ e-mail: temitope.akintunde@uniosun.edu.ng
}

DOI: 10.51865/EITC.2021.03.08

\begin{abstract}
Developing countries in the factor-driven stage of development are usually bedevilled by domestic supply-side constraints which hinder translation of their comparative advantages to development. This study examines the domestic supply-side determinants to intra-Africa export performance in selected African countries. The study analysed 1994 to 2019 panel data of the biggest economies in each of the five African sub-regions, using pooled mean group (PMG) technique. The result from the study revealed capital formation, institutional quality, macroeconomic stability, technology adoption and infrastructure as significant long-run determinants of intra-Africa export performance while size of labour force was found to be insignificant long-run determinant of intra-Africa export share. All short-run coefficients of explanatory variables except one period lag of infrastructure and capital formation were insignificant. The coefficient of error correction term was negative and statistically significant. Based on the findings of this study macroeconomic stability, infrastructural development, pro-market institutions, capital formation and technology adoption are imperative for intra-Africa export performance in the studied countries.
\end{abstract}

Keywords: export performance; economic integration; competitiveness; supply-side constraint.

JEL Classification: $F 14 ; F 15 ; F 43 ; H 4$.

\section{Introduction}

The relationship between external trade and development and the policies required to synergize the duo for development have always attracted the attention of researchers and policy makers, given the diverse experience of nations and regions of the world with international trade (Panitchpakdi, 2007). In time past, exports from developing countries been unable to compete favourably in the global market, given unfavourable international division of labour between developed and developing countries. Consequently, policy makers in developing countries have long resorted to sub-regional economic integration for development and as a training ground for global competitiveness (Yang \& Gupta, 2005). However, only advance developing countries

\footnotetext{
${ }^{*}$ Corresponding author
} 
such as china, Singapore and Taiwan which are able to progress into the efficiency stage of development have achieved remarkable improvement in export performance and global competitiveness. Majorly due to their ability to take advantage of the new international division of labour in which developing countries develop the capability to efficiently engage in simpler stages manufacturing while the developed economies engage in sophisticated manufacturing activities. Replicating this feat in Africa is one of the major reasons for regional and subregional economic integration in Africa (Todaro and Smith 2015).

The inability of African countries to progress from factor driven stage of development to efficiency driven stage of development has been attributed to their over-reliance on primary product exports export. Given Africa's abundant human and non-human natural resources, economic integration will undoubtedly be a step towards global competitiveness of African export. However, most African countries are currently bedevilled with myriad long-lasting socioeconomic constraints which are both cause and effect of their overreliance on primary product export which subsequently prevents maximization of comparative advantages and development benefits of their natural endowments (Todaro and Smith, 2015). Given economic integration, overcoming this challenge often requires removal of domestic constraints to the production and export of goods and services in which participants have comparative advantages (Oladipupo and Adedoyin, 2019; Schwab and Sala-i-Martin 2014). Given the dissuasion of state ownership and other forms of protectionist intervention in economic integration, policy makers may be unwilling to promote export through distortive policies (Lall, 2000). Consequently, government may resort to policies targeted towards improving domestic market supply capacity and competitiveness. For developing countries in the factor-driven stage of development, this may mean pursuit of sound institutions, well-developed infrastructure, stable macroeconomic environment and a healthy and a literate workforce which enables efficient exploitation of their natural endowment (Marchat and Verdier-Chouchane, 2017). Given the foregoing this study seeks to investigate which supply side determinants of export are relevant for intra-Africa export performance?

The reviewed literature on the determinants of export performance reveals the existence of empirical studies conducted which analysed firm, industry and country level data from different parts of the world using different methodologies. However, it is also evident that the effects of the different determinants of export performance are mixed. The contradicting results present a research gap which needs to be filled in other guide policies on export performance in practice. Besides studies on determinants of intra-Africa export of are relatively scarce. Thus, this study intends to investigate domestic supply side determinants of intra-Africa export performance of selected African countries.

\section{Literature Review}

\section{Theoretical review}

Export performance/competitiveness is one of the most common concepts among trade-led economic development policy makers and theorists interested in maximizing benefits from international trade agreements. Mercantilism is an economic form of nationalism targeted at achieving economic, political and military supremacy through improved export performance. This is achieved through state protection of domestic firms (majorly Monopolists and cartels) from external competition and internal competition; restriction of imports and their consumption and restraint of silver and gold export. Hence, mercantilism sees export performance as a zerosum game in which one party benefits at the expense of the other (La Haye 2008). Conversely, theory of absolute advantage opines that mercantilists mix of import restriction and export promotion and zero-sum game view of international trade is contradictory since other countries whose export was restricted could retaliate by restricting import from the mercantilist country. 
Hence, Smith advocated free trade, international specialisation and division of labour by highlighting the principle of absolute advantage in which parties in free trade agreements benefit from trade provided each have absolute advantage in at least one sector of its economy (Smith 1975).

The theory of absolute advantage may however not explain dynamic modern economies where competitive advantage relies more on early adoption of technological advancements, product differentiation, and adequacy of local infrastructure, low cost and skilled labour force or better business environment than pre-existing natural advantage. Similarly the theory cannot explain international trade involving vertical integration in which a country needs to depend on others for inputs in its productive sectors. Furthermore, the theory of absolute advantage did not explicitly state the role of government intervention in international specialisation (Voinescua and Moisoiu, 2015). The theory of comparative advantage further expands knowledge about export performance. According to Ricardo international specialisation and division of labour is driven by relative advantage which is viewed as opportunity cost. Countries will produce and export goods in which they have lowest opportunity cost compared to their trading partners and import goods in which they have higher opportunity cost from their trading partners. Hence for two countries to be trade partners, they must both be able to produce what their partner cannot produce at better opportunity cost (Ricardo 1817).

The principle of comparative advantage however fails to explain the rationale for trade between countries with similar comparative advantage and opportunity cost and high factor mobility. It also fails to acknowledge other factors of international competitiveness. Finally, the model also failed to explain the role of government in international specialisation and division of labour (Voinescua and Moisoiu, 2015). Although, comparative cost differences has been widely accepted as the source of competitiveness in international trade, the theory of comparative cost advantage have been widely criticised particularly for assuming comparative cost differences without explaining how it occur (Avadhani2009).

The Hecksher-Ohlin (H-O) theory however solves this problem by explaining differences in factor price as the cause of relative commodity price and comparative advantages rather than assuming it. The H-O assumption of similar technology use by trade partners implies that competitive advantage does not rely on technology has been heavily criticised in that in reality developing countries may be victims of poverty trap as technological gap between developed and developing nations widens in the long run (Voinescua and Moisoiu 2015). This assumption may however be right for regional trade between developing countries in the short run. Worthy of note is the Leontief paradox which tends to negate the H-O model. Leontief (1953) in his empirical test of the H-O model using USA data discovered that the USA with higher capital per worker exported goods that were labour intensive than capital intensive. According to product life-cycle hypothesis the Leontief paradox may be due to the fact that labour intensive manufactures are first exported from countries where they are invented before production occur in other countries of the world (Vernon 1979). Hence, Leontief paradox may be due to relative endowment with highly skilled human capital capable of inventing labour intensive products.

\section{Empirical review}

Bhavan (2016) investigated the determinants of export performance from 1980 to 2013 employing Johansen co-integration and vector error correction model. The findings of the study revealed that in the long run, investment, interest payment on foreign debt and import have positive impact on export performance while gross capital formation and per capita income of export destination exhibits negative relationship. In the short run, foreign direct investment and per capita income of export destination countries significantly affect export performance while import, gross capital formation and interest payment are insignificant. Conversely, Feddersen, Nel and Botha (2017) studied exports, capital formation and economic growth in South Africa from First quarter of 1975 to last quarter in 2012 employing Johansen's co integration 
procedure, impulse response functions, variance decomposition analysis and Granger causality tests. The result from the study revealed that export growth directly influence economic growth in the short run while its positive effect on economic growth in the long run occurs through its ability to expand capital formation. Based on the findings of the study it was concluded that symbiotic relationship exists between export growth and capital formation. Several other studies also confirm a relationship between export performance and economic growth. Several other studies also confirmed a positive relationship between export performance and capital formation (Kanu and Ozurumba 2014; Mogaji and Falade 2020; Udude et al 2017)

Abraham and Sasikumar, (2011) studied the effect of labour cost on export performance of Indian export performance of the Indian Textile \& Clothing industry using tobit estimation technique. The findings of the study suggested a negative relationship between labour cost export performance of Indian Textile and Clothing industry. Furthermore, the use of low labour cost as means of improved export performance in Indian Textile and Clothing industry increased after the implementation of the implementation of the Agreement on Textile and Clothing (ATC) of the World Trade Organization (WTO). Decramer, Fuss and Konings (2016) investigated the effect of unit labour cost on export performance from 1999 to 2010 using Belgian firm-level data. The findings of the study shows that increase in unit labour cost reduce the likelihood of non-exporting firms to start exporting and increase the probability of exporting-firms to stop exporting. Furthermore, the effect of unit labour cost on the number of labour employed and how much they work on the average is relatively low, implying that the increased unit labour cost does not result in substantial increase in price. Golub et al. (2018) examined sub-Saharan Africa's (SSA) bilateral trade and cost competitiveness. The findings of the study revealed that African relative unit labour costs declined over the 2000s as Chinese wages increased faster than its productivity while the reverse was the case for the SSA countries studied. The study concluded that SSA countries are unlikely to be competitive in labourintensive goods export given a combination high relative unit labour cost and weak business climate.

Tsoukis (2016) investigated the government size and institution features on export performance of a panel of 18 OECD countries from 1980 to 2005 . The finding of the study revealed that a tax receipt of around $40-45 \%$ of GDP is the export-maximizing government size while the best size of productive government spending is $16 \%$ of GDP. Product market and labour market distortions caused by government intervention have negative effect on export performance singlehandedly and via negative effect on research and development and slow down of speed of adjustment. Araujo, Mion and Ornelas (2016) investigated the effect of contract enforcement and export experience shape firm export dynamics in an environment with incomplete information of a panel of Belgian exporting firms from 1995 to 2008. The findings of the study suggest that firms from countries with institution capable of enforcing contracts and firms with prior foreign experience are more likely to start with higher volume of export and survive in the international market for longer periods. Efobi and Osabuohien (2016) investigate the effect of the level of infrastructural and institutional development on the extent of manufacturing export in ECOWAS countries. The findings of the study revealed that poor infrastructural development which hampers the manufacturing export and competitiveness of ECOWAS countries results from institutions which promotes private gains rather than public good (infrastructure).

Celbis et al (2014) investigated the determinants of export performance using the data on bilateral export from 26 Turkish regions to 180 countries from 2002 to 2010 . The findings of the study suggests that land infrastructure, air transport capacity, private maritime infrastructure presence, together with the distance of regional economies to ports and airports are key determinants of export performance. Portugal-Perez and Wilson, (2012) examines the impact of aggregate indicators of soft and hard infrastructure on the export performance of 100 developing countries from 20014 to 2007 . The findings of the study showed that trade facilitation reforms improve export performance especially if combined with investment in physical infrastructure 
and regulatory reform which improve business environment. Furthermore, the impact of physical infrastructure and information and communications technology on exports becomes more important as the country becomes richer.

Ejemeyovwi (2017) in a study of the effect of information and communication technology adoption on human development using and Generalise Methods of Moments (GMM) and Granger causality test discovered a statistically significant positive relationship between internet usage and investment in telecommunications, while mobile cell subscription was found to have a statistically insignificant relationship with human development. Furthermore, the findings from the study revealed that ICT adoption does not granger cause human development at the intermediate and next annual time period. Sener and Delican (2019) studied the causal relationship between innovation, competitiveness and foreign trade in 31 developed and 26 developing countries using Dumitrescu and Hurlin Panel causality test. The study revealed a unidirectional causality from export to innovation and information-communication technology and from information-communication technology to competitiveness in both developed and developing countries. However, unlike developed countries, developing countries were also found to show unidirectional causality from competitiveness to export and from innovation to competitiveness, showing a different trade dynamics in both side of the divide.

Albarran, Carrasco and Holl(2013) studied the impact of domestic transport cost reductions on firms export market participation on firms export market participation of a panel of Spanish manufacturing firms using geographic information system techniques. The result of the study revealed a positive effect of domestic transport infrastructure improvements on small and medium-sized firms' possibility of exporting. Babiker, Abdullah and Al-Feel (2011) studied the export competitiveness of Sudanese live sheep and mutton using policy analysis technique. The results of the study showed that Sudanese livestock export amounts to $22 \%$ of its total export after meeting domestic demand for meat and that live sheep and mutton export was found to be profitable because domestic price of mutton and live sheep is lesser than the border price. In addition, Sudanese sheep market achieved external competitiveness despite being informally organised, lacking in basic infrastructure (transportation) and systematic marketing research. The study concluded that the contribution livestock in general and sheep in particular to GDP will be greater than the current $19 \%$ if the livestock sector is formalised and adequate business environment is made available by the government.

Hussain and Mazhar (2018) estimated the impact of demand and supply side factors on the export performance of Pakistan from 1971 to 2015 using unrestricted autoregressive distributive lag model (ARDL) and conclude based on the findings of the study that although both demand and supply side factors are equally important in explaining export behaviour at the aggregate level, supply side factors have relatively high impact on export performance at a disaggregated level. Lall (2000) considered turkey prospect in manufacture export given its reliance on labourintensive export; its characteristics of being a high wage economy and its subscription to European Union free trade agreement. The findings of the study shows that Turkey comparative advantage in labour-intensive export is ephemeral as it has to compete with both low wage European economies and technological advanced European economies. Based on the findings of the study further development Turkish good skill base to attract assembly and component plants; development and encouragement of technology which enable SMEs efficiency and access to information on foreign markets, designs and expansion of its capability through purposeful diversification into technology-intensive activities is recommended for sustained export competitiveness.

Epaphra (2016) studied the determinants of export performance in Tanzania between 1966 and 2015 using Johansen co-integration and Granger causality approach. The findings of the study suggested that real per capita GDP, trade liberalization and exchange rate have direct relationship with export performance while official development assistant and inflation have an indirect relationship with export performance. Furthermore, the results reveal unidirectional 
causality from per capita GDP to export showing that policies directed towards improvement of real per capita GDP must be prioritised for enhanced export performance. Snieskiene and Cibinskiene (2015) investigated how export price can be made more competitive, using systemic and comparative scientific literature analysis. The findings of the study revealed that export price competitiveness mostly depends on exchange rate fluctuations, inflation rates, customer perceived value, customer sophistication, channels of distribution, competitive intensity, company's size, export experience, degree of product differentiation, stage of product life-cycle, and production costs. Furthermore the dynamism of export pricing requires proactive solutions and adjustable export pricing decisions.

\section{Methodology}

\section{Data description and sources}

This study analysed annual panel data of the five biggest economies in each of the 5 African sub- regions based on 2019 nominal GDP values. Specifically, the countries studied are Nigeria, South Africa, Egypt, Kenya and DR Congo. The rationale behind the choice of countries is that big African economies are more likely to compete favourably globally and serve as model to smaller African countries in intra-Africa export. The study covered the period 1994 to 2019. The choice of study period is guided by data availability. Panel study is chosen due to its appropriateness in addressing the study objective and its ability to circumvent data shortage challenges common to developing countries. The data collected were analysed with Eviews 10. Table 1 presents the proxies, description and sources of the data analysed in the study.

Table 1. Variable description

\begin{tabular}{|c|c|c|c|}
\hline Variables & Proxy & Data Sources & Description \\
\hline $\begin{array}{l}\text { Export } \\
\text { Performance } \\
\text { (EXP) }\end{array}$ & $\begin{array}{l}\text { Merchandise } \\
\text { exports to low- } \\
\text { and middle- } \\
\text { income } \\
\text { economies in } \\
\text { Sub-Saharan } \\
\text { Africa }\end{array}$ & $\begin{array}{l}\text { World } \\
\text { Development } \\
\text { Indicators }\end{array}$ & $\begin{array}{l}\text { Country's percentage of merchandise exports } \\
\text { to low- and middle-income economies in the } \\
\text { Sub-Saharan Africa region. }\end{array}$ \\
\hline $\begin{array}{l}\text { Capital Formation } \\
\text { (CAP) }\end{array}$ & $\begin{array}{l}\text { Gross capital } \\
\text { formation }\end{array}$ & $\begin{array}{l}\text { World } \\
\text { Development } \\
\text { Indicators }\end{array}$ & $\begin{array}{l}\text { Percentage of GDP expended on additions to } \\
\text { fixed assets of the economy plus net changes } \\
\text { in the level of inventories as percentage of } \\
\text { GDP. This includes construction of } \\
\text { schools, roads, railways, and hospitals, and } \\
\text { private residential dwellings. }\end{array}$ \\
\hline $\begin{array}{l}\text { Labour Force } \\
\text { (LAB) }\end{array}$ & Labour Force & $\begin{array}{l}\text { World } \\
\text { Development } \\
\text { Indicators }\end{array}$ & $\begin{array}{l}\text { People age } 15 \text { and older who are currently } \\
\text { employed and people who are unemployed } \\
\text { but seeking work as well as first-time job- } \\
\text { seekers during a specific period. }\end{array}$ \\
\hline $\begin{array}{l}\text { Institution Quality } \\
\text { (INS) }\end{array}$ & $\begin{array}{l}\text { Regulatory } \\
\text { Quality }\end{array}$ & $\begin{array}{l}\text { World } \\
\text { Governance } \\
\text { Indicators }\end{array}$ & $\begin{array}{l}\text { Perceptions of the ability of the government } \\
\text { to formulate and implement sound policies } \\
\text { and regulations that permit and promote } \\
\text { private sector development. }\end{array}$ \\
\hline $\begin{array}{l}\text { Infrastructure } \\
\text { (INF) }\end{array}$ & $\begin{array}{l}\text { Access to } \\
\text { electricity }\end{array}$ & $\begin{array}{l}\text { World } \\
\text { Development } \\
\text { Indicators }\end{array}$ & $\begin{array}{l}\text { Percentage of population with access to } \\
\text { electricity. }\end{array}$ \\
\hline
\end{tabular}


Table 1 (cont.)

\begin{tabular}{llll}
\hline $\begin{array}{l}\text { Macroeconomic } \\
\text { Stability }\end{array}$ & $\begin{array}{l}\text { Inflation, } \\
\text { (consumer } \\
\text { prices) }\end{array}$ & $\begin{array}{l}\text { World } \\
\text { Development } \\
\text { Indicators }\end{array}$ & $\begin{array}{l}\text { Annual percentage change in the cost to the } \\
\text { average consumer of acquiring a basket of } \\
\text { goods and services. }\end{array}$ \\
$\begin{array}{l}\text { Technology } \\
\text { Adoption (TEC) }\end{array}$ & $\begin{array}{l}\text { Individuals using } \\
\text { the Internet (\% } \\
\text { of population) }\end{array}$ & $\begin{array}{l}\text { World } \\
\text { Development } \\
\text { Indicators }\end{array}$ & $\begin{array}{l}\text { Individuals who have used the Internet (from } \\
\text { any location) in the last 3 months }\end{array}$ \\
\hline
\end{tabular}

Source: Authors' compilation, 2021.

\section{Model specification}

A framework of analysis to determine the effects of various supply side factors of export performance of selected African countries is developed by considering potential domestic supply side constraint to export relevant to African business environment. Although, literature records other factors such as trade liberalisation and exchange rate as determinants of export performance, we excluded these factors with the assumption that only supply-side factors constrain export performance. Consequently, Capital formation, labour force size, institution, infrastructure, technology adoption and macroeconomic stability are included as explanatory variables in the estimation model. These variables were chosen based on the realities obtainable in African economic environment. The specified equation for export performance is as follows;

$$
E X P=f(C A P, L A B, I N S, I N F, T E C, S T A)
$$

To directly obtain the individual effect of each regressor on intra-Africa export performance, the following explicit regression model is formed from equation (1):

$E X P_{i t}=\beta_{0 i}+\beta_{1} C A P_{i t}+\beta_{2} \log L A B_{i t}+\beta_{3} I N S_{i t}+\beta_{4} I N F_{i t}+\beta_{5} T E C_{i t}+\beta_{6} S T A_{i t}+e_{i t}$

Apriori Expectation:

$$
\beta_{1}>0, \beta_{2}>0, \beta_{3}>0, \beta_{4}>0, \beta_{5}>0, \beta_{6}<0
$$

In generalized Panel ARDL (p, q, q...q) specifically with the Pooled Mean Group form we have:

$$
\Delta Y_{i t}=\theta_{i}\left[Y_{i, t-1}-\lambda_{i}^{\prime} X_{i, t}\right]+\sum_{j=1}^{p-1} \delta_{i j} \Delta Y_{i, t-j}+\sum_{j=0}^{q-1} \beta^{\prime}{ }_{i j} \Delta X_{i, t-j}+\varphi_{i}+e_{i t}
$$

Where:

$Y_{i t}$ : isthedependentvariable (EXP);

$\theta_{i}:$ group - specificspeedofadjustmentcoefficient (expectedtobe $<0$ );

$\left[Y_{i, t-1}-\lambda_{i}^{\prime} X_{i, t}\right]=$ ErrorCorrectionTerm;

$X_{i t}$ : are the independent variables (CAP, LAB, INS, INF,TEC, STA);

$\delta_{i j}$ : is the coefficient of the lagged dependent variable;

$\beta_{i j}^{\prime}, \delta_{i j}$ : are short-run dynamic coefficients;

$\lambda_{i}^{\prime}$ : vector of longrun relationships;

$\varphi_{i}:$ unit specific fixed effects;

$p$, q: are optimal lag orders;

$i$ : number from $1 \ldots N$;

t: numberfrom $1 \ldots T$;

$e_{i t}$ : error term.

\section{Estimation technique}

The pooled mean Group (PMG) technique is used to estimate the stated model. This method is an intermediated estimation method which assumes short run group specific intercepts, coefficients and error variances, and restricts long run coefficients to be homogeneous across 
the study groups. The Pooled mean group technique is intermediate in that it combines the averaging feature of mean group (MG) estimation technique which allows both long-run and short run estimates to vary across groups and the pooling feature of dynamic fixed effect technique (DFE) which restricts long run and short run slope coefficients and error variances to be the same (Shin, Smith and Pesaran, 1998).

Shin, Smith and Pesaran (1998) assumes that all the variables in the PMG model is either integrated of order one $\mathrm{I}(0)$ and order two $\mathrm{I}(1)$; imperfectly correlated and a negative and significant error correction term (ECT). However scholars are divided as to whether the maximum absolute value of ECT should be 1 or 2. According to Olarewaju et al, (2017) the ECT must be less than 1, negative and significant. Conversely, Loayza and Lanciere (2004) opined that absolute value of the ECT must be negative and not exceed 2. Narayan and Smyth (2006) however concluded that an ECT absolute value between 1 and 2 suggests an error correction process which rapidly converges to equilibrium path after fluctuating around the long run value in a dampening manner.

The Im, Peseran and Shin unit root test and Levin, Lin and Chu unit root test is used to ensure that all variables in the study are $\mathrm{I}(0)$ and $\mathrm{I}(1)$. Given the size of $\mathrm{N}$ and $\mathrm{T}$, Pesaran cross sectional dependence test is used to ensure that our estimates are not affected by cross-sectional dependence. Correlation matrix for the variables is used to ensure that no two variables in our model are perfectly correlated. The optimal lag structure of the model is automatically chosen using Akaike Information Criterion.

\section{Results}

Table 2 presents the descriptive statistics. The median value of intra-Africa export shows that the countries under study export more outside Africa. The median values of the independent variables also show that there is room for more improvement in capital formation, institutional quality, technology adoption, macroeconomic stability and infrastructure. However the median value of labour force size shows that the countries under study are blessed with an army of labour. The probability of Jarque-Berra statistics shows that all variables except Institutional quality reject the null hypothesis of normality. The panel is balanced as there are 130 observations for all variables.

Table 2. Descriptive statistics

\begin{tabular}{lccccccc}
\hline & EXP & CAP & LAB & INS & TEC & STA & INF \\
Median & 13.37582 & 18.49686 & 21598103 & -0.370000 & 5.300000 & 9.074694 & 50.28812 \\
Jarque-Bera & 11.27671 & 47.65552 & 36.09954 & 2.443382 & 87.95992 & 85018.07 & 11.26949 \\
Probability & 0.003559 & 0.000000 & 0.000000 & 0.294731 & 0.000000 & 0.000000 & 0.003572 \\
Observations & 130 & 130 & 130 & 130 & 130 & 130 & 130 \\
\hline
\end{tabular}

Source: Authors' computation, 2021.

Table 3 presents the correlation matrix. The pair wise correlation coefficients in the correlation matrix confirm that no two explanatory variables in our study have exact negative or positive correlation.

Table 3. Correlation matrix

\begin{tabular}{|c|c|c|c|c|c|c|c|}
\hline & EXP & CAP & LAB & INS & INF & TEC & STA \\
\hline EXP & 1 & & & & & & \\
\hline CAP & -0.08 & 1 & & & & & \\
\hline LAB & -0.43 & 0.32 & 1 & & & & \\
\hline INS & 0.09 & 0.06 & -0.32 & 1 & & & \\
\hline INF & -0.58 & 0.05 & 0.09 & 0.55 & 1 & & \\
\hline TEC & -0.08 & -0.09 & 0.20 & 0.26 & 0.52 & 1 & \\
\hline STA & -0.06 & -0.15 & -0.07 & -0.14 & -0.14 & -0.07 & 1 \\
\hline
\end{tabular}

Source: Authors' computation, 2021. 
Table 4 presents the result of the Levin-Lin-Chu and Im-Pesaran-Shin (IPS) Panel Unit-root tests. The probability values of both tests confirm at $5 \%$ level of significance that no variable in the study is integrated of order two [ I(2)].

Table 4. Levin-Lin-Chu and Im-Pesaran-Shin (IPS) Panel Unit-root test

\begin{tabular}{|l|l|l|l|l|l|c|}
\hline \multirow{2}{*}{ Variable } & \multicolumn{3}{|c|}{$\begin{array}{c}\text { LLC } \\
\text { (Assumes Common Unit Root) }\end{array}$} & \multicolumn{3}{c|}{$\begin{array}{c}\text { IPS } \\
\text { (Assumes Individual Unit Root) }\end{array}$} \\
\hline & Order & Probability & Order & Probability \\
\hline EXP & $\mathrm{I}(0)$ & Intercept & 0.0135 & $\mathrm{I}(0)$ & Intercept & 0.0290 \\
\hline CAP & $\mathrm{I}(1)$ & Intercept & 0.0000 & $\mathrm{I}(1)$ & Intercept & 0.0000 \\
\hline LAB & $\mathrm{I}(1)$ & Intercept & 0.0180 & $\mathrm{I}(1)$ & Intercept & 0.0058 \\
\hline INS & $\mathrm{I}(1)$ & Intercept & 0.0000 & $\mathrm{I}(0)$ & Intercept & 0.0018 \\
\hline INF & $\mathrm{I}(1)$ & Intercept & 0.0047 & $\mathrm{I}(1)$ & Intercept & 0.0000 \\
\hline STA & $\mathrm{I}(0)$ & Intercept & 0.0000 & $\mathrm{I}(0)$ & Intercept & 0.0000 \\
\hline TEC & $\mathrm{I}(0)$ & Intercept & 0.0000 & $\mathrm{I}(0)$ & Intercept & 0.0000 \\
\hline
\end{tabular}

Source: Authors' computation, 2021.

Table 5 presents the result of the Pesaran scaled cross sectional dependence tests for each of the variable in the study. The probability values of the test statistics for intra-Africa export, labour force size, Infrastructure, macroeconomic stability and technology adoption rejects the null hypothesis of cross sectional independence at $1 \%$ level of significance while the probability value for capital formation and institutional quality fails to reject the null hypothesis of cross sectional independence at $5 \%$ level of significance.

Table 5. Cross sectional dependence test

\begin{tabular}{llllllll}
\hline $\mathrm{H}_{0}$ : Cross Sectiona Independence & \multicolumn{7}{l}{} \\
\hline Variable & EXP & CAP & LOG(LAB) & INS & INF & STA & TEC \\
\hline Pesaran & 3.354248 & -1.361438 & 15.73875 & 1.054076 & 11.93959 & 3.879313 & 13.64012 \\
Scaled CD & $(0.0008)$ & $(0.1734)$ & $(0.0000)$ & $(0.2918)$ & $(0.0000)$ & $(0.0001)$ & $(0.0000)$ \\
\hline
\end{tabular}

Source: Authors' computation, 2021.

Table 6 presents the result of the Akaike Information Criterion and Hannan-Quinn criterion for optimal lag selection. The Akaike Information Criterion (AIC) choose Lag structure $(2,2,2,2$, $2,2,2)$ with the least AIC value $(4.548859)$ as the optimal lag for the panel ARDL model.The Hannan-Quinn Criterion also validates the choice lag structure.

Table 6. Optimal lag selection

\begin{tabular}{|c|c|c|c|}
\hline Model & AIC* & HQ & SPECIFICATION \\
\hline 4 & 4.548859* & 5.312968 & $\overline{\operatorname{ARDL}(2,2,2,2,2,2,2)}$ \\
\hline 2 & 4.690336 & 5.407277 & $\operatorname{ARDL}(1,2,2,2,2,2,2)$ \\
\hline 1 & 4.974976 & 5.408914 & $\operatorname{ARDL}(1,1,1,1,1,1,1)$ \\
\hline 3 & 5.041751 & 5.522856 & $\operatorname{ARDL}(2,1,1,1,1,1,1)$ \\
\hline
\end{tabular}

Source: Authors' computation, 2021 using E-views 10 Statistical Package.

Table 7 presents the long-run estimates, short-run estimates and error correction term of the panel ARDL model. All the long-run coefficients of the explanatory variables except labour force size agree with a priori expectation and are statistically significant at $5 \%$ level. The longrun coefficient of capital formation implies that a $1 \%$ increase in gross capital formation will yield $0.13 \%$ increase in intra-Africa export. The long-run coefficient of institutional quality implies that a unit increase in institutional quality will yield $2.24 \%$ increase in intra-Africa export performance. The long-run coefficient of infrastructure implies that $1 \%$ increase in access to infrastructure will yield $0.21 \%$ increase in export. The long-run coefficient of technology adoption implies that a $1 \%$ increase in technology adoption will yield a $0.12 \%$ increase in intra-Africa export. The long-run co-efficient of macroeconomic stability implies that a $1 \%$ increase in macroeconomic stability will yield $0.04 \%$ increase in export performance. 
All the short-run coefficients of the explanatory variables except one period lag of capital formation and electricity are insignificant. However, only one period lag of capital formation agrees with a priori expectation. The one period lag coefficient of capital formation implies that $1 \%$ increase in current year capital formation will yield previous year capital formation will yield $0.196 \%$ increase in intra-Africa export performance in the subsequent year. Conversely, the one period lag coefficient of infrastructure implies that $1 \%$ increase in infrastructure in the current year will yield $0.401 \%$ decrease in intra-Africa. The coefficient of error correction term (ECT) is negative and less than 1 in absolute value. The coefficient of ECT value suggests an above average speed of adjustment of short-run deviation from long-run equilibrium. This shows that about $69 \%$ of the deviation from long-run equilibrium Intra-Africa export performance is corrected yearly. Specifically it takes about $1.45(1 / 687461)$ yearsfor the previous year deviation from long-run equilibrium to be corrected. The probability value of the Pesaran cross sectional dependency test statistics shows that our estimates were not affected by cross sectional dependence.

Table 7. P-ARDL estimates and error correction term

\begin{tabular}{|c|c|c|c|c|}
\hline \multicolumn{5}{|c|}{ Dependent Variable: EXP } \\
\hline Variable & Coefficient & Stand. Error & t-Statistics & Probability \\
\hline \multicolumn{5}{|c|}{ Long-Run Estimates } \\
\hline CAP & 0.134256 & 0.046929 & 2.860849 & 0.0062 \\
\hline LOG(LAB) & -1.116427 & 2.773369 & -0.402553 & 0.6890 \\
\hline REG & 2.244398 & 0.505823 & 4.437123 & 0.0001 \\
\hline ELE & 0.207490 & 0.085806 & 2.418124 & 0.0194 \\
\hline INF & -0.037024 & 0.009224 & -4.013780 & 0.0002 \\
\hline INT & 0.115573 & 0.013493 & 8.565121 & 0.0000 \\
\hline \multicolumn{5}{|c|}{ Short-Run Estimates } \\
\hline ECT & -0.687461 & 0.326381 & -2.106317 & 0.0403 \\
\hline $\mathrm{D}(\operatorname{EXP}(-1))$ & 0.192223 & 0.131777 & 1.458695 & 0.1510 \\
\hline $\mathrm{D}(\mathrm{CAP})$ & -0.109652 & 0.120036 & -0.913494 & 0.3655 \\
\hline $\mathrm{D}(\mathrm{CAP}(-1)$ & 0.196089 & 0.056692 & 3.458879 & 0.0011 \\
\hline $\mathrm{D}(\mathrm{LAB})$ & -34.72916 & 46.77799 & -0.742425 & 0.4614 \\
\hline $\mathrm{D}(\mathrm{LAB}(-1))$ & 34.14094 & 32.02055 & 1.066220 & 0.2915 \\
\hline $\mathrm{D}(\mathrm{REG})$ & -2.768005 & 3.919588 & -0.706198 & 0.4834 \\
\hline $\mathrm{D}(\mathrm{REG}(-1))$ & 2.864089 & 4.284426 & 0.668488 & 0.5070 \\
\hline $\mathrm{D}$ (ELE) & -0.238997 & 0.133138 & -1.795103 & 0.0788 \\
\hline $\mathrm{D}(\operatorname{ELE}(-1))$ & -0.401120 & 0.148373 & -2.703452 & 0.0094 \\
\hline $\mathrm{D}(\mathrm{INF})$ & -0.012554 & 0.056293 & -0.223013 & 0.8245 \\
\hline $\mathrm{D}(\mathrm{INF}(-1)$ & 0.041410 & 0.053712 & 0.770955 & 0.4444 \\
\hline $\mathrm{D}(\mathrm{INT})$ & -0.525343 & 0.627325 & -0.837433 & 0.4064 \\
\hline $\mathrm{D}(\mathrm{INT}(-1))$ & -0.079854 & 0.193697 & -0.412263 & 0.6819 \\
\hline CONSTANT & 12.57209 & 5.752311 & 2.185572 & 0.0337 \\
\hline Pesaran C D & & & & 0.8383 \\
\hline
\end{tabular}

Source: Authors' computation, 2021.

\section{Discussion}

The positive impact of capital formation on intra-Africa export confirms the theoretical and empirical conclusions that more capital formation is required for developing countries to maximize the comparative advantages of their abundant human and non-human resources (Feddersen, Nel and Botha 2017; kanu and Ozurumba 2014; Mogaji and Falade 2020; Udude et al 2017). Given the importance of infrastructure to productive activities, production cost and by extension export competitiveness, it is unsurprising that infrastructure have a positive impact on export performance. Development of infrastructure may also improve intra-Africa export 
through attraction of foreign direct investment (Vijil and Wagner 2012; Kadochnikov and Fedyunina 2018). The negative and insignificant impact of labour force size negates apriori expectations. This may be due to prevalence of unemployment and underemployment which may be attributed to the shortage of capital needed to engage surplus labour in productive activities. This may also emphasize the importance of labour force quality in intra-Africa export performance and specialization in labour intensive exports.

The positive significant relationship between institutional quality and with intra-African export agrees with empirical studies which conclude that sound public institutions capable of formulating and implementing pro market policies and regulations are required for sustained export performance (Tsoukis 2016; Araujo, Mion and Ornelas 2016; Efobi and Osabuohien 2016). Similarly the negative relationship between macroeconomic stability and intra-Africa export is expected as stable macroeconomyhave been found to have adverse effect on export competitiveness through its impact on exchange rate, interest rate and cost of production (Fugazza 2014). The positive relationship between technology adoption and intra-Africa export performance is expected as it agrees with empirical studies which concludes that technology adoption improve export performance through access to information about new markets, design and efficient production process and customer relation (Makanyeza and Ndlovu (2015); Kotnik and Hagsten (2018); Racela and Thoumrungroje 2020).

\section{Conclusion}

While export performance is pertinent to development, African countries are continually bedevilled by supply-side constraint which prevents maximization of the comparative advantage from their abundant human and non-human resources. This study investigates the domestic supply-side determinants of export performance of the biggest economies in each of the five African sub-regions. The study covered the period of 26 years from 1994 to 2019. Using the Pooled Mean Group technique to analyse the annual panel data of these countries, this study established that capital formation, Institutional quality, Infrastructure, macroeconomic stability and technology adoption are significant long-run determinants of intra-Africa export performance. Based on these findings, drastic infrastructural development, sound public institutions, macroeconomic stability and adoption of technology are pertinent for the improvement of intra-Africa export and eventual global competitiveness of African export.

\section{References}

1. Abraham, V. and Sasikumar, S. K., 2011. Labour cost and export behaviour of firms in Indian textile and clothing industry. Economics, Management \& Financial Markets, 6(1).

2. Albarran, P., Carrasco, R. and Holl, A., 2013. Domestic transport infrastructure and firms' export market participation. Small Business Economics, 40(4), pp.879-898.

3. Araujo, L., Mion, G., and Ornelas, E., 2016. Institutions and export dynamics. Journal of International Economics, 98, 2-20.

4. Avadhani, V. A., 2009. Securities analysis and portfolio management. Himalaya Publishing House.

5. Babiker, B. I., Abdullah, A. J. M., and Al-Feel, M. A., 2011. Sudanese live sheep and mutton exports competitiveness. Journal of the Saudi Society of Agricultural Sciences, 10(1), 25-32.

6. Bhavan, T., 2016. The determinants of export performance: the case of Sri Lanka. International Research Journal of Social Sciences, 5(8), 8-13.

7. Celbis, M. G., Nijkamp, P. and Poot, J., 2014. Infrastructure and the international export performance of Turkish regions. UNU-MERIT Working Papers, (021).

8. Decramer, S., Fuss, C. and Konings, J., 2016. How do exporters react to changes in cost competitiveness? The World Economy, 39(10), 1558-1583. 
9. Efobi, U. R. and Osabuohien, E. S., 2016. Manufacturing Export, Infrastructure and Institutions: Reflections from ECOWAS.InAccelerated Economic Growth in West Africa (pp. 157179).Springer, Cham.

10. Ejemeyovwi, J. O., 2017. Information and Communication Technology Adoption And Inclusive Growth In West Africa (Doctoral dissertation, Covenant University, Ota, Nigeria.).

11. Epaphra, M., 2016.Determinants of export performance in Tanzania. Journal of Economics Library, 3(3), 470-487.

12. Menji, S., 2010.Export Performance and Determinants in Ethiopia MPRA Paper no. 29427]. University of Munich, Research Papers in Economics, Munich Personal RePEc Archive.

13. Feddersen, M., Nel, H. and Botha, F., 2017.Exports, capital formation and economic growth in South Africa. African Review of Economics and Finance, 9(1), 213-244.

14. Fugazza, M., 2004. Export performance and its determinants: supply and demand constraints. Available at SSRN 1281486.

15. Golub, S. S., Ceglowski, J., Mbaye, A. A. and Prasad, V., 2017. Can Africa compete with China in manufacturing? The role of relative unit labour costs. The World Economy, 41(6), 1508-1528.

16. Hussain, S. I., \& Mazhar, U., 2018. Estimated export demand and supply functions for Pakistan: A disaggregated analysis. Pakistan Business Review, 20(1), 222-234.

17. LaHaye, 2008. Mercantilism. The concise encyclopedia of economics, Library of Economics and Liberty. Retrieved September 13, 2014 from http://www.econlib.org/library/Enc/Mercantilism.html.

18. Loayza, N. and Ranciere, R., 2004. Financial development, financial fragility, and growth. The World Bank.

19. Macdonald, J.M., 1994. Does import competition force efficient production? Review of Economics and Statistics, 76: 721-727.

20. Marchat, J. M., \& Verdier-Chouchane, A., 2017.The Africa Competitiveness Report 2017: Addressing Africa's demographic dividend. Geneva: World Economic Forum.

21. Kadochnikov, S.M. and Fedyunina, A.A., 2018. Explaining the performance of Russian export: what role does the soft and hard infrastructure play?. International Journal of Economic Policy in Emerging Economies, 11(6), pp.541-559.

22. Kanu, S. I. and Ozurumba, B. A., 2014. Capital formation and economic growth in Nigeria. Global Journal of human-social science: Economics, 14(4), 43-58.

23. Kotnik, P., and Hagsten, E., 2018. ICT use as a determinant of export activity in manufacturing and service firms: Multi-country evidence. ZbornikradovaEkonomskogfakulteta u Rijeci/Proceedings of Rijeka Faculty of Economics, 36(1), 103-128.

24. Lall, S., 2000. Turkish performance in exporting manufactures: a comparative structural analysis. Queen Elizabeth House.

25. Akbar, M., Naqvi, Z. F, and Iqbal, Z., 2001.External Market Conditions, Competitiveness, Diversification, and Pakistan's Export Performance with Comments]. The Pakistan Development Review, 871-884.

26. Leontief, W., 1953. Domestic production and foreign trade; the American capital position reexamined. Proceedings of the American philosophical Society, 97(4), 332-349.

27. Makanyeza, C. and Ndlovu, A., 2015. ICT and Export Performance: Empirical Evidence from Small and Medium Enterprises in the Manufacturing Sector Of Zimbabwe. In Conference on Business Innovation and Growth (p.152).

28. Narayan, P. K. and Smyth, R., 2006. What determines migration flows from low-income to high-income countries? An empirical investigation of Fiji-Us migration 1972-2001. Contemporary Economic Policy, 24(2), 332-342.

29. Oladipupo, O. and Adedoyin, F., 2019. Determinants of Bilateral Trade Flows of Nigeria: An Application of the Augmented Gravity Model. Available at SSRN 3439986.

30. Olarewaju, O. M., Sibanda, M, and Migiro, S. O., 2017. Dynamics of Lintner's model in the dividend payment process of Nigerian banks. SPOUDAI - Journal of Economics and Business, 67(3), 79-94.

31. Pal, R., 2018. Heckscher - Ohlin and other theories https://www.researchgate.net/publication/ $\underline{323388547}$

32. Panitchpakdi, S., 2007. Preface.in United Nations Developing countries in international trade 2007: Trade and development index. United Nations, iii.

33. Portugal-Perez, A. and Wilson, J. S., 2012. Export performance and trade facilitation reform: Hard and soft infrastructure. World development, 40(7), 1295-1307. 
34. Racela, O. C. and Thoumrungroje, A., 2020. Enhancing export performance through proactive export market development capabilities and ICT utilization. Journal of Global Marketing, 33(1), 4663.

35. Ricardo, D., 1817. On the principles of political economy and taxation. 1821. Library of Economics and Liberty. Consultado el, 31 .

36. Schwab, K.. and Sala-i-Martin, X., 2014. The global competitiveness report 2014 2015. In World Economic Forum (Vol. 549, pp. 36-38).

37. Sener, S. and Delican, D., 2019. The causal relationship between innovation, competitiveness and foreign trade in developed and developing countries. Procedia Computer Science, 158, 533-540.

38. Shin, Y., Smith, R. P. and Pesaran, M. H., 1998. Pooled mean group estimation of dynamicheterogeneous panels (No. 16). Edinburgh School of Economics, University of Edinburgh.

39. Smith, A., 1975.The Theory of International Trade. Essays on Adam Smith. Clarendon Press: Oxford, 472 .

40. Snieskiene, G. and Cibinskiene, A., 2015. Export price: How to make it more competitive. Procedia-Social and Behavioral Sciences, 213, 92-98.

41. Udude, C. C., Odo, S. I., Ituma, S. O. and Elom-Obed, F. O., 2017. Investigating the impact of oil export on gross capital formation in Nigeria. Asian Research Journal of Arts \& Social Sciences, 2(4), 1-12.

42. Vernon, R., 1979. The product cycle hypothesis in a new international environment. Oxford bulletin of economics and statistics, 41(4), 255-267.

43. Vijil, M. and Wagner, L., 2012. Does aid for trade enhance export performance? Investigating the infrastructure channel. The World Economy, 35(7), pp.838-868.

44. Todaro, M. P. and Smith, S. C., 2015.Economic development. Pearson Education Limited.

45. Tsoukis, C., 2016. The welfare state, institutions and export performance. Economic Modelling, 53, $37-47$.

46. Voinescu, R. and Moisoiu, C., 2015. Competitiveness, theoretical and policy approaches. Towards a more competitive EU. Procedia Economics and Finance, 22(1), 512-521.

47. Yang, Y. and Gupta, S., 2005. Regional trade arrangements in Africa. InternationalMonetary Fund. $\mathrm{WP} / 20 / 30$. 